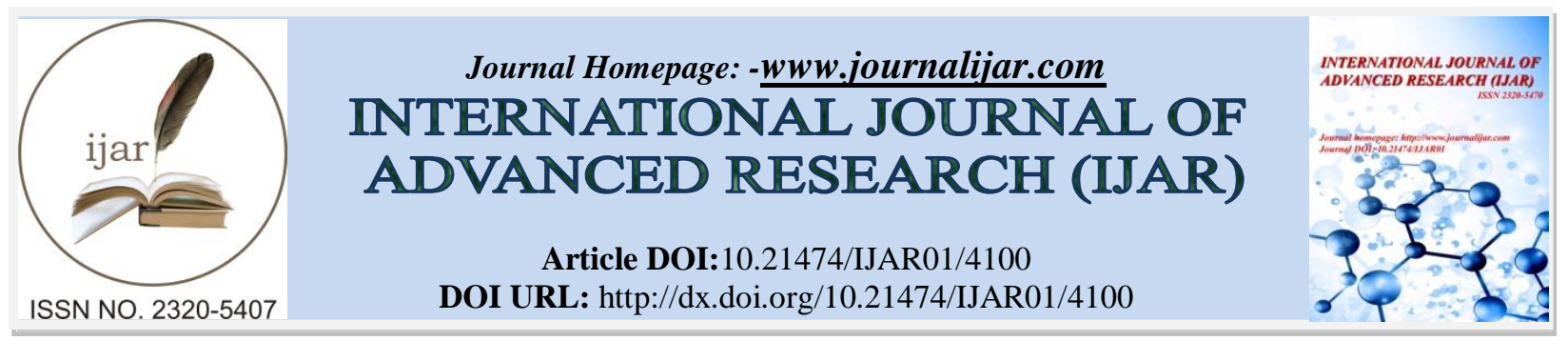

RESEARCH ARTICLE

\title{
NEEDS DURING BED REST IN HIGH RISK PREGNANCY: A NARRATIVE REVIEW
}

Pooja Mishra ${ }^{1}$, AS Agasthiya ${ }^{2}$, Dr.Nageshwar $V^{2}$ and Dr. NV Munninarayanappa ${ }^{3}$.

1. M.Sc Nursing Final Year, Teerthanker Mahaveer College of Nursing, Teerthanker Mahaveer UniversityDelhi Road, Moradabad, India

2. Assistant Professor, TeerthankerMahaveer College of Nursing, Teerthanker Mahaveer University Delhi Road, Moradabad, India

3. Principal, TeerthankerMahaveer College of Nursing, Teerthanker Mahaveer University Delhi Road, Moradabad, India

\section{Manuscript Info}

Manuscript History

Received: 07 March 2017

Final Accepted: 11 April 2017

Published: May 2017

Key words:-

high risk pregnancy, bed rest, needs.

\section{Abstract}

Background: Pregnancy in women's life is considered unique and natural period. But when the pregnancy is at high risk, it is recommended to limit activity and treated with bed rest which disturbs natural process of pregnancy. The women develop some needs during the journey of bed rest and want support to get them fulfilled for better maternal and fetal outcome.

Objective: To undertake a narrative review so as to explore the needs of high risk pregnant women during bed rest.

Method: 8 studies were selected from a period of 1991-2016 after keyword searches for PubMed, EBSCO, DELNET databases and google scholarly articles. Manual searches of other relevant journals and reference list of primary articles were also done.

Results: 8 studies were selected for this narrative review including 5 qualitative and 3 quantitative studies. Data analysis of 4 of the studies reported the needs of high risk pregnant women during bed rest like need for consultation due to physical problems, psychological problems, marital problems, fear and stress, need for planning various activities during bed rest, need for counselling on psychological problems, need for social support, need for assistance with emotional adaptation and bed rest. Remaining 4 studies discussed about anxiety, stress, depression and worries faced by women which are factors for arousing specific needs during bed rest in high risk pregnancy.

Conclusion: Bed rest interrupts the natural process of pregnancy due to which high risk pregnant mother may sometime feel isolated. During hospitalization, the high risk pregnant mother has high level of stress, anxiety and worries. So, nurse should have a sense of responsibility to assess the needs of high risk pregnant mother and can take help of family members to cope up with the situation.

Copy Right, IJAR, 2017,. All rights reserved. 


\section{Introduction:-}

Hippocrates first used bed rest as a therapy and is very commonly recommended intervention in high risk pregnancy despite of known physiological and psychological side effects (Sprague, 2004). Over 1 million pregnant women in a year are identified with obstetrical complications and nearly 700,000 among them are treated with bed rest. A recent guideline (2012) from The American College of Obstetricians and Gynaecologists of the management of preterm birth states that the use of routinely recommended activity restriction should be avoided, as the therapy has not been shown to be effective.

A high risk pregnancy is one which is complicated by one or more factors that adversely affects the outcome of pregnancy - maternal or perinatal or both. The types of complications that make a pregnancy high risk include: premature rupture of membranes, preterm labor, placenta previa, diabetes, multiple gestation, hypertension, suspected fetal growth retardation\& vaginal bleeding (Maloni, 2010).

Most of the high risk mothers undergo "bed rest" that is limited ambulation of not more than 1-2 hours per day with use of bathroom and bathing permitted (Science Daily,2014). Pregnancy complicated with high risk conditions is a very tough situation for pregnant woman, as the usual adaption to pregnancy is disturbed. Now the woman has to adjust with different situation caused by her high risk condition (Heaman, 1998). Hospitalized high risk pregnant women during bed rest expressed their concerns about family, another children, household works and financial issue that put more psychological pressure on these women (Granheim\&Lundman, 2004).

Antenatal hospitalization is associatedwith several numbers of stressors, such as separation fromfamily, home and boredom. Some specific stressorssuch as bed rest, lack of activity, hospitalization,tests and treatments, feelings of uncertaintyand lack of control is experienced by high-riskpregnant women.Depression, anxiety and other stressful feelingsduring prenatal period easily lead to more severediseases which may be sometimes harmful to the mother, fetusand the expectant newborn's health (Qiao et al., 2009)

This activity restriction disturbs the natural process of pregnancy with several problems and thus the mother develops some specific needs to cope with this situation, which needs to be understood and managed by the health care professionals.

To address the issue and to identify the needs of high risk pregnant women on bed rest, this narrative review was undertaken so that it would help the health care professionals to understand and manage these needs as well as to provide comprehensive health care to high risk pregnant women during bed rest.

\section{Methods:-}

Search strategy Methods:-

Articles were searched from PubMed, EBSCO, DELNET databases and google scholarly articles. Manual searches of other relevant journals and reference list of initial search articles were referred. Articles in English language were only accepted. Articles with sample of age group less than 18 years of age were excluded.

\section{Key words searched:-}

High risk pregnancy, bed rest and needs.

\section{Period focused:-}

The review focused mainly from the period of 1991 to 2016.

\section{Types of Interventions:-}

Home visits.

\section{Types of Studies:-}

Qualitative study, explorative, descriptive, randomized trial, descriptive correlational study, phenomenological, grounded theory, cross sectional descriptive study and quantitative study. 


\section{Types of Participants:-}

High risk pregnant mothers, family members, hospital staff, antenatal women at risk of delivering low birth weight baby, non-pregnant women and women with normal pregnancy.

\section{Settings:-}

Private midwifery clinic, obstetric care clinics, private hospitals, public health centres and university hospital.

\section{Outcomes:-}

Understanding the needs and problems experienced by high risk pregnant women during bed rest.

Approach for conducting the narrative review started with search for literature that are related to the topic "Needs during bed rest in high risk pregnancy". Following initial search a total of 36 articles were found related to different conditions of high risk pregnancy. A total of 28 articles were excluded out of which 13 were abstract, 6 were systematic reviews, 8 were not useful and one was dissertation. The remaining 8 were relevant to the topic and included for this review. It consists of 5 qualitative and 3 quantitative studies which were conducted in South Africa, Iran, Mexico City, France, United States, Danish\&Dallas.

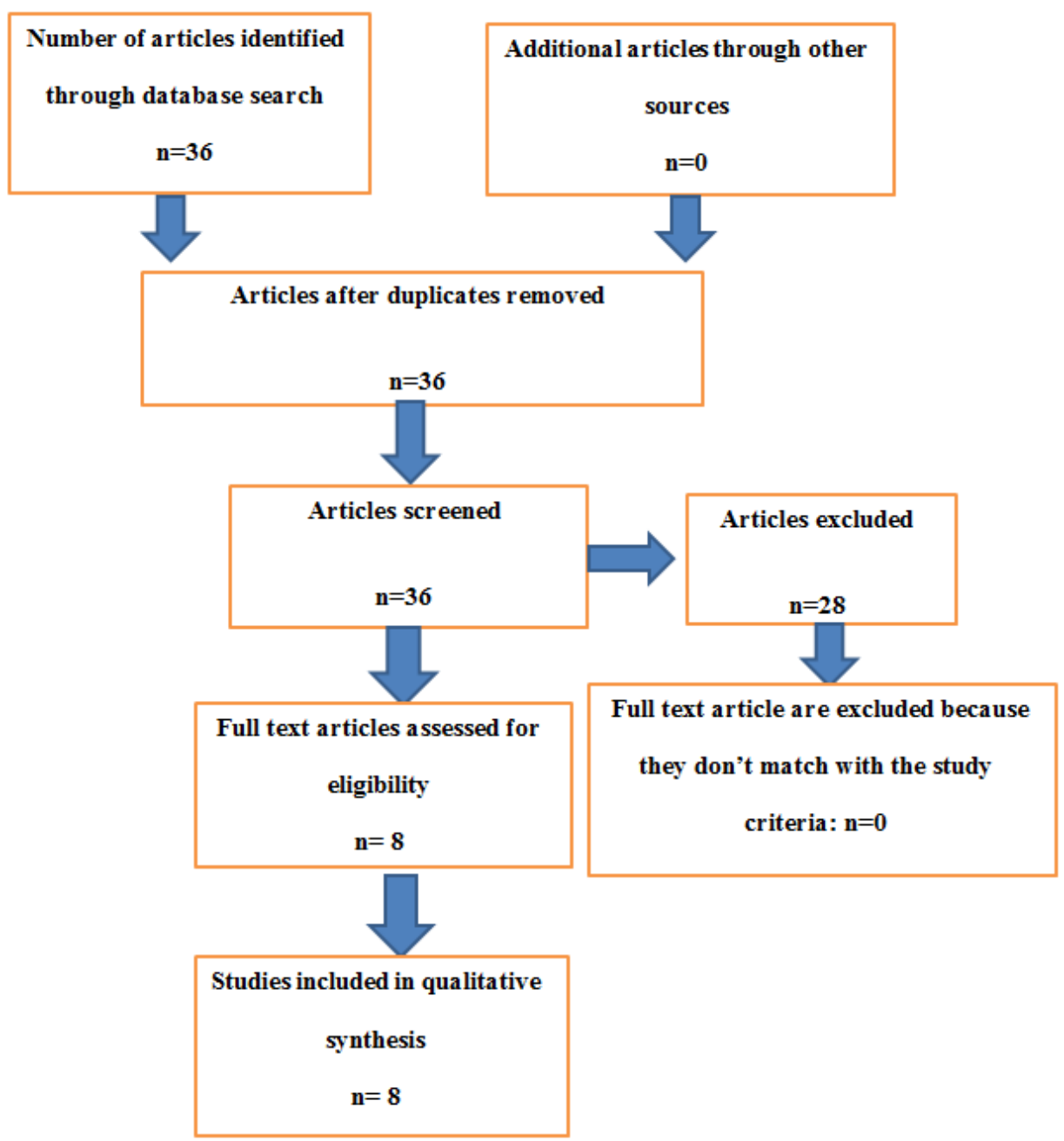

Fig. 1:-Prisma Flow Chart. 
Table 1:- Summary of Study Characteristics

\begin{tabular}{|c|c|c|c|c|c|c|c|}
\hline $\begin{array}{l}\text { S.No } \\
\text {. }\end{array}$ & $\begin{array}{l}\text { Problem } \\
\text { statement/Aut } \\
\text { hor }\end{array}$ & $\begin{array}{l}\text { Place of } \\
\text { researc } \\
\text { h \& \& } \\
\text { year }\end{array}$ & $\begin{array}{l}\text { Varia } \\
\text { bles }\end{array}$ & Tools & $\begin{array}{l}\text { Time } \\
\text { duration }\end{array}$ & Outcomes & Remark \\
\hline 1. & $\begin{array}{l}\text { The support } \\
\text { needs of high- } \\
\text { risk antenatal } \\
\text { patients in } \\
\text { prolonged } \\
\text { hospitalization. } \\
\text { „ } \\
\text { Roxane Agnes } \\
\text { Kent } \\
\text { MariathaYazbe } \\
\text { k } \\
\text { Tanya Heyns } \\
\text { Isabel Coetzee. }\end{array}$ & $\begin{array}{l}\text { Study } \\
\text { conduct } \\
\text { ed in } \\
\text { South } \\
\text { Africa" } \\
2014\end{array}$ & $\begin{array}{l}\text { Supp } \\
\text { ort } \\
\text { needs } \\
\text { of } \\
\text { high- } \\
\text { risk } \\
\text { pregn } \\
\text { ant } \\
\text { wome } \\
\text { n }\end{array}$ & $\begin{array}{l}\text { In-depth } \\
\text { interview } \\
\mathrm{s}\end{array}$ & $20-40 \mathrm{~min}$ & $\begin{array}{l}\text { Findings } \\
\text { resulted in } \\
\text { three main } \\
\text { themes: need } \\
\text { for social } \\
\text { support, } \\
\text { assistance with } \\
\text { emotional } \\
\text { adaptation, } \\
\text { environment } \\
\text { improvement } \\
\text { and accepting } \\
\text { prolonged } \\
\text { hospitalization }\end{array}$ & $\begin{array}{l}\text { In high risk pregnancy, } \\
\text { the usual adaption to } \\
\text { pregnancy is disturbed } \\
\text { due to prolonged } \\
\text { hospitalization due to } \\
\text { which women develop } \\
\text { some specific needs. } \\
\text { This study further } \\
\text { recommends making } \\
\text { strategies to meet the } \\
\text { support needs of these } \\
\text { women. }\end{array}$ \\
\hline \multirow[t]{2}{*}{2.} & $\begin{array}{l}\text { Problem } \\
\text { statement/Aut } \\
\text { hor }\end{array}$ & $\begin{array}{l}\text { Place of } \\
\text { researc } \\
\text { h \& } \\
\text { year }\end{array}$ & $\begin{array}{l}\text { Varia } \\
\text { bles }\end{array}$ & Tools & $\begin{array}{l}\text { Time } \\
\text { duration }\end{array}$ & Outcomes & Remark \\
\hline & $\begin{array}{l}\text { "Need for } \\
\text { Consultation } \\
\text { and Training } \\
\text { during bed rest } \\
\text { in women with } \\
\text { High-risk } \\
\text { pregnancy } \\
\text { experience: A } \\
\text { Qualitative } \\
\text { Study." } \\
\text { MojganJanighor } \\
\text { ban, } \\
\text { FatemehMoham } \\
\text { madi } \\
\text { Maryam } \\
\text { Allahdadian } \\
\text { AzamDadkhah } \\
\text { Ahmad- } \\
\text { aliEslami, }\end{array}$ & $\begin{array}{l}\text { Study is } \\
\text { conduct } \\
\text { ed in } \\
\text { Iran. } \\
2016\end{array}$ & $\begin{array}{l}\text { Need } \\
\text { for } \\
\text { Cons } \\
\text { ultati } \\
\text { on } \\
\text { and } \\
\text { Traini } \\
\text { ng }\end{array}$ & $\begin{array}{l}\text { Semi- } \\
\text { structure } \\
d \\
\text { Interview }\end{array}$ & $60-90 \mathrm{~min}$ & $\begin{array}{l}\text { Data analysis } \\
\text { led to the } \\
\text { emerging of } \\
\text { themes such as } \\
\text { need for } \\
\text { consultation } \\
\text { on physical } \\
\text { problems, } \\
\text { psychological } \\
\text { problems, } \\
\text { marital } \\
\text { problems, fear } \\
\text { and stress } \\
\text { caused due to } \\
\text { prolonged bed } \\
\text { rest and } \\
\text { common } \\
\text { problems of } \\
\text { pregnancy and } \\
\text { child birth. }\end{array}$ & $\begin{array}{l}\text { High risk pregnant } \\
\text { mothers needs some } \\
\text { support } \\
\text { prolonged bed rest. } \\
\text { Providing effective } \\
\text { nursing care, education } \\
\text { and counselling to } \\
\text { women on bed rest due } \\
\text { to high risk category } \\
\text { would reduce their } \\
\text { physical and } \\
\text { psychosocial problems. }\end{array}$ \\
\hline \multirow[t]{2}{*}{3.} & $\begin{array}{l}\text { Problem } \\
\text { statement/Aut } \\
\text { hor }\end{array}$ & $\begin{array}{l}\text { Place of } \\
\text { researc } \\
\text { h \& \& } \\
\text { year }\end{array}$ & $\begin{array}{l}\text { Varia } \\
\text { bles }\end{array}$ & Tools & $\begin{array}{l}\text { Time } \\
\text { duration }\end{array}$ & Outcomes & Remark \\
\hline & $\begin{array}{l}\text { "A randomized } \\
\text { trial of } \\
\text { psychosocial } \\
\text { support during } \\
\text { high risk } \\
\text { pregnancy." } \\
\text { Jose Villar } \\
\text { UbaldoFarnot } \\
\text { Fernando }\end{array}$ & $\begin{array}{l}\text { Study is } \\
\text { conduct } \\
\text { ed in } \\
\text { Brazil, } \\
\text { Havana, } \\
\text { Cuba } \\
\text { and } \\
\text { Mexico } \\
\text { city. }\end{array}$ & $\begin{array}{l}\text { Indep } \\
\text { enden } \\
\mathrm{t} \\
\text { variab } \\
\text { le- } \\
\text { Psych } \\
\text { osoci } \\
\text { al } \\
\text { Supp }\end{array}$ & $\begin{array}{l}\text { Four } \\
\text { home } \\
\text { visits } \\
\text { were } \\
\text { made. } \\
\text { Each } \\
\text { visit of } \\
1-2 \\
\text { hours. }\end{array}$ & 1-2 hours & $\begin{array}{l}\text { During each } \\
\text { home visit, } \\
\text { mother } \\
\text { discussed } \\
\text { about her } \\
\text { pregnancy } \\
\text { especially } \\
\text { changes, } \\
\text { worries or }\end{array}$ & $\begin{array}{l}\text { The study but reveals } \\
\text { the fact that high risk } \\
\text { pregnant mothers have } \\
\text { some worries and } \\
\text { doubts which emerge } \\
\text { the need for supporting } \\
\text { the mental health status } \\
\text { of women in this crucial } \\
\text { time. The study also }\end{array}$ \\
\hline
\end{tabular}




\begin{tabular}{|c|c|c|c|c|c|c|c|}
\hline & $\begin{array}{l}\text { Barros } \\
\text { Cesar Victoria, } \\
\text { M.D } \\
\text { Ana Langer, } \\
\text { M.D } \\
\text { Jose M Belizan, } \\
\text { M.D }\end{array}$ & 1991 & $\begin{array}{l}\text { ort } \\
\text { Depe } \\
\text { ndent } \\
\text { variab } \\
\text { le- } \\
\text { high } \\
\text { risk } \\
\text { pregn } \\
\text { ancy }\end{array}$ & $\begin{array}{l}\text { Health } \\
\text { educatio } \\
\mathrm{n}, \\
\text { discussio } \\
\mathrm{n} \text { of } \\
\text { specific } \\
\text { topics } \\
\text { and } \\
\text { encourag } \\
\text { ement on } \\
\text { use of } \\
\text { health } \\
\text { services } \\
\text { was part } \\
\text { of home } \\
\text { visit. }\end{array}$ & & $\begin{array}{l}\text { doubts. The } \\
\text { interventions } \\
\text { designed to } \\
\text { provide } \\
\text { psychological } \\
\text { support and } \\
\text { health } \\
\text { education } \\
\text { during high } \\
\text { risk pregnancy } \\
\text { does not } \\
\text { improve the } \\
\text { maternal } \\
\text { health status } \\
\text { and the } \\
\text { incidence of } \\
\text { low birth } \\
\text { weight among } \\
\text { infants. }\end{array}$ & $\begin{array}{l}\text { says that there is need } \\
\text { for some supportive } \\
\text { programs for the } \\
\text { pregnant mother during } \\
\text { high risk pregnancy. }\end{array}$ \\
\hline 4. & $\begin{array}{l}\text { Problem } \\
\text { statement/Aut } \\
\text { hor }\end{array}$ & $\begin{array}{l}\text { Place of } \\
\text { research } \\
\& \text { year }\end{array}$ & $\begin{array}{l}\text { Va } \\
\text { ria } \\
\text { ble } \\
\text { s }\end{array}$ & Tools & $\begin{array}{l}\text { Time } \\
\text { duration }\end{array}$ & Outcomes & Remark \\
\hline & $\begin{array}{l}\text { 'Factors } \\
\text { implicated in } \\
\text { moderating the } \\
\text { risk for } \\
\text { depression and } \\
\text { anxiety in high } \\
\text { risk } \\
\text { pregnancy." } \\
\text { A. Denis, } \\
\text { P. Michaux } \\
\text { and S. Callahan }\end{array}$ & $\begin{array}{l}\text { Study is } \\
\text { conducted } \\
\text { in South of } \\
\text { France area } \\
2012\end{array}$ & \begin{tabular}{|l} 
So \\
cia \\
1 \\
sup \\
por \\
t, \\
sel \\
f- \\
est \\
ee \\
m, \\
co \\
pin \\
g \\
str \\
ate \\
gie \\
s \\
aff \\
ect \\
de \\
pre \\
ssi \\
ve \\
an \\
d \\
an \\
xio \\
us \\
sy \\
mp \\
to \\
ms.
\end{tabular} & $\begin{array}{l}\text { Question } \\
\text { naires }\end{array}$ & --- & $\begin{array}{l}\text { The results } \\
\text { showed that } \\
\text { over half of } \\
\text { the high risk } \\
\text { pregnant } \\
\text { women } \\
\text { manifested } \\
\text { symptoms of } \\
\text { pre-natal } \\
\text { depression and } \\
\text { all sample } \\
\text { showed high } \\
\text { levels of } \\
\text { anxiety symptoms. } \\
\text { This study } \\
\text { underscores } \\
\text { the importance } \\
\text { of providing } \\
\text { appropriate } \\
\text { psychological } \\
\text { support for } \\
\text { high risk } \\
\text { pregnant } \\
\text { women in } \\
\text { order to avoid } \\
\text { depressive } \\
\text { disorders. }\end{array}$ & $\begin{array}{l}\text { The study shows that it } \\
\text { is important for the } \\
\text { pregnant mother to be } \\
\text { emotionally supported } \\
\text { during high-risk } \\
\text { condition to help her to } \\
\text { adjust with the } \\
\text { situation. Psychological } \\
\text { problems like } \\
\text { depression could be } \\
\text { benefitted from } \\
\text { psychological support, } \\
\text { and this would be best } \\
\text { implemented by } \\
\text { focusing on issues } \\
\text { surrounding high-risk } \\
\text { pregnancy. So, group } \\
\text { therapy for hospitalised } \\
\text { women may provide } \\
\text { some emotional support } \\
\text { to women who might } \\
\text { otherwise feel isolated } \\
\text { from family and friends. }\end{array}$ \\
\hline
\end{tabular}




\begin{tabular}{|c|c|c|c|c|c|c|c|}
\hline 5. & $\begin{array}{l}\text { Problem } \\
\text { statement/Aut } \\
\text { hor }\end{array}$ & $\begin{array}{l}\text { Place of } \\
\text { research } \\
\text { \& year }\end{array}$ & $\begin{array}{l}\text { Va } \\
\text { ria } \\
\text { ble } \\
\text { s } \\
\end{array}$ & Tools & $\begin{array}{l}\text { Time } \\
\text { duration }\end{array}$ & Outcomes & Remark \\
\hline & $\begin{array}{l}\text { "Spiritual well- } \\
\text { being, anxiety } \\
\text { and depression } \\
\text { in antepartal } \\
\text { women on bed } \\
\text { rest." } \\
\text { Linda L. Dunn } \\
\text { Marilyn C. } \\
\text { Handley, } \\
\text { Tuscaloosa, } \\
\text { Alabama, } \\
\text { Marvin } \\
\text { Mitchell } \\
\text { Shelton }\end{array}$ & $\begin{array}{l}\text { Study is } \\
\text { conducted } \\
\text { in south- } \\
\text { eastern } \\
\text { United } \\
\text { States. } \\
2007\end{array}$ & $\begin{array}{l}\text { Spi } \\
\text { ritu } \\
\text { al } \\
\text { we } \\
\text { ll- } \\
\text { bei } \\
\text { ng, } \\
\text { an } \\
\text { xie } \\
\text { ty, } \\
\text { an } \\
\text { d } \\
\text { de } \\
\text { pre } \\
\text { ssi } \\
\text { on }\end{array}$ & $\begin{array}{l}\text { Spiritual } \\
\text { Well- } \\
\text { Being } \\
\text { Scale } \\
\text { (SWBS; } \\
\text { Ellison, } \\
\text { 1983), } \\
\text { and the } \\
\text { subscales } \\
\text { from the } \\
\text { Abbrevia } \\
\text { ted Scale } \\
\text { for the } \\
\text { Assessm } \\
\text { ent of } \\
\text { Psychoso } \\
\text { cial } \\
\text { Status in } \\
\text { Pregnanc } \\
\text { y } \\
\text { (ASAPS } \\
\text { P; Goldenb } \\
\text { erg et } \\
\text { al.,1997) }\end{array}$ & --- & $\begin{array}{l}\text { The result } \\
\text { found that } \\
\text { woman with } \\
\text { high risk } \\
\text { pregnancy had } \\
\text { high level of } \\
\text { depression and } \\
\text { anxiety and } \\
\text { low level of } \\
\text { spiritual } \\
\text { wellbeing. }\end{array}$ & $\begin{array}{l}\text { The study provides } \\
\text { awareness regarding the } \\
\text { mental and spiritual } \\
\text { needs of high risk } \\
\text { pregnant women on bed } \\
\text { rest. It is important that } \\
\text { the nurses should be } \\
\text { accountable to assess } \\
\text { the level of spiritual } \\
\text { wellbeing of high risk } \\
\text { antenatal women. As } \\
\text { obstetricians often } \\
\text { manage high risk } \\
\text { pregnant condition with } \\
\text { bed rest therefore, it is } \\
\text { essential that nurses } \\
\text { should meet the } \\
\text { spiritual needs of these } \\
\text { women. Further studies } \\
\text { can be done on these } \\
\text { women to decrease } \\
\text { depression and anxiety } \\
\text { and increase spiritual } \\
\text { wellbeing to improve } \\
\text { maternal and fetal } \\
\text { outcomes. }\end{array}$ \\
\hline 6. & $\begin{array}{l}\text { Problem } \\
\text { statement/Aut } \\
\text { hor }\end{array}$ & $\begin{array}{l}\text { Place of } \\
\text { research } \\
\text { \& year }\end{array}$ & $\begin{array}{l}\text { Va } \\
\text { ria } \\
\text { ble } \\
\text { s }\end{array}$ & Tools & $\begin{array}{l}\text { Time } \\
\text { duration }\end{array}$ & Outcomes & Remark \\
\hline & $\begin{array}{l}\text { High-Risk } \\
\text { Pregnancy and } \\
\text { Hospitalization: } \\
\text { The Women's } \\
\text { Voices } \\
\\
\text { Ronit D. } \\
\text { Leichtentritt, } \\
\text { Nurith } \\
\text { Blumenthal, } \\
\text { AnatElyassi, } \\
\text { and } \\
\text { SigiRotmensc }\end{array}$ & $\begin{array}{l}\text { Study is } \\
\text { conducted } \\
\text { in Israel } \\
2005\end{array}$ & $\begin{array}{l}\text { Be } \\
\text { d } \\
\text { Re } \\
\text { st } \\
\text { dur } \\
\text { ing } \\
\text { hig } \\
\text { h } \\
\text { ris } \\
\text { k } \\
\text { pre } \\
\text { gn } \\
\text { anc } \\
\text { y }\end{array}$ & $\begin{array}{l}\text { Group } \\
\text { interview } \\
\mathrm{s}\end{array}$ & 1-2 hours & $\begin{array}{l}\text { Results had } \\
\text { recognized } \\
\text { five themes: } \\
\text { the personal } \\
\text { and social } \\
\text { meaning of a } \\
\text { family, the } \\
\text { desire to } \\
\text { nurture and the } \\
\text { social } \\
\text { pressure, loss } \\
\text { of normal } \\
\text { experience of } \\
\text { pregnant life } \\
\text { and } \\
\text { childbearing, } \\
\text { the woman's } \\
\text { needs versus } \\
\text { the needs of } \\
\text { fetal well- } \\
\text { being and } \\
\text { sources of }\end{array}$ & $\begin{array}{l}\text { Bed rest for a long } \\
\text { period of time is a tough } \\
\text { experience for pregnant } \\
\text { women at high risk. } \\
\text { Understanding the } \\
\text { themes and meeting } \\
\text { needs of pregnant } \\
\text { women confined to bed } \\
\text { rest may assist nurses in } \\
\text { developing } \\
\text { interventions for better } \\
\text { outcomes of this period } \\
\text { of bed rest. }\end{array}$ \\
\hline
\end{tabular}




\begin{tabular}{|c|c|c|c|c|c|c|c|}
\hline & & & & & & $\begin{array}{l}\text { strength and } \\
\text { stress. }\end{array}$ & \\
\hline 7. & $\begin{array}{l}\text { Problem } \\
\text { statement/Aut } \\
\text { hor }\end{array}$ & $\begin{array}{l}\text { Place of } \\
\text { research } \\
\text { \& year }\end{array}$ & $\begin{array}{l}\text { Va } \\
\text { ria } \\
\text { ble } \\
\text { S }\end{array}$ & Tools & $\begin{array}{l}\text { Time } \\
\text { duration }\end{array}$ & Outcomes & Remark \\
\hline & $\begin{array}{l}\text { "Pregnant } \\
\text { women's } \\
\text { management of } \\
\text { activity } \\
\text { restriction } \\
\text { during } \\
\text { hospitalisation: } \\
\text { A question of } \\
\text { yielding and not } \\
\text { feeling deprived } \\
\text { of a sense of } \\
\text { control." } \\
\text { Jane Bendix, } \\
\text { Hanne } \\
\text { Kjaergaard\&Vi } \\
\text { bekeZoffmann }\end{array}$ & $\begin{array}{l}\text { Study is } \\
\text { conducted } \\
\text { in Danish. } \\
2013\end{array}$ & $\begin{array}{l}\text { Ac } \\
\text { tivi } \\
\text { ty } \\
\text { res } \\
\text { tric } \\
\text { tio } \\
\mathrm{n} \\
\text { dur } \\
\text { ing } \\
\text { hos } \\
\text { pit } \\
\text { alis } \\
\text { ati } \\
\text { on }\end{array}$ & $\begin{array}{l}\text { Semi - } \\
\text { structure } \\
\mathrm{d} \\
\text { interview } \\
\mathrm{s}\end{array}$ & --- & $\begin{array}{l}\text { All women } \\
\text { shared feeling } \\
\text { of being } \\
\text { without sense } \\
\text { of control and } \\
\text { feeling } \\
\text { involuntarily } \\
\text { deprived. } \\
\text { Themes } \\
\text { emerged were: } \\
\text { being in a } \\
\text { helpless and } \\
\text { dependent } \\
\text { state, having to } \\
\text { find meaning, } \\
\text { having to put } \\
\text { aside her } \\
\text { personal } \\
\text { values, } \\
\text { tolerating } \\
\text { limitations of } \\
\text { freedom. }\end{array}$ & $\begin{array}{l}\text { Identifying and } \\
\text { understanding the } \\
\text { challenging dimensions } \\
\text { of activity restriction } \\
\text { during hospitalisation } \\
\text { can guide health care } \\
\text { professionals } \\
\text { providing support to } \\
\text { pregnant women. }\end{array}$ \\
\hline 8. & $\begin{array}{l}\text { Problem } \\
\text { statement/Aut } \\
\text { hor }\end{array}$ & $\begin{array}{l}\text { Place of } \\
\text { research } \\
\text { \& year }\end{array}$ & $\begin{array}{l}\text { Va } \\
\text { ria } \\
\text { ble } \\
\text { s }\end{array}$ & Tools & $\begin{array}{l}\text { Time } \\
\text { duration }\end{array}$ & Outcomes & Remark \\
\hline & $\begin{array}{l}\text { "Prenatal } \\
\text { Depression in } \\
\text { Women } \\
\text { Hospitalized for } \\
\text { Obstetric Risk." } \\
\text { Anna R. } \\
\text { Brandon, } \\
\text { Madhukar H. } \\
\text { Trivedi, Linda } \\
\text { S. Hynan,Paula } \\
\text { D. } \\
\text { Miltenberger, } \\
\text { Dana Broussard } \\
\text { Labat, Jamie B. } \\
\text { Rifkin\&C. } \\
\text { Allen Stringer. }\end{array}$ & $\begin{array}{l}\text { Study is } \\
\text { conducted } \\
\text { in Dallas } \\
2008\end{array}$ & $\begin{array}{l}\text { Pre } \\
\text { nat } \\
\text { al } \\
\text { De } \\
\text { pre } \\
\text { ssi } \\
\text { on }\end{array}$ & $\begin{array}{l}\text { Self- } \\
\text { report } \\
\text { questiona } \\
\text { ire,Struct } \\
\text { ured } \\
\text { clinical } \\
\text { interview } \\
\text {, Semi- } \\
\text { structure } \\
\mathrm{d} \\
\text { interview }\end{array}$ & 14 months & $\begin{array}{l}\text { Forty-four } \\
\text { percent of the } \\
\text { hospitalized } \\
\text { high risk } \\
\text { pregnant } \\
\text { women had } \\
\text { depressive } \\
\text { symptoms and } \\
\text { the rate of } \\
\text { depressive } \\
\text { disorder was } \\
\text { 19 \% higher } \\
\text { than previous } \\
\text { normal } \\
\text { pregnancy. } \\
\text { There was no } \\
\text { significant } \\
\text { relationship } \\
\text { between } \\
\text { severity of } \\
\text { obstetrical risk } \\
\text { and maternal } \\
\text { fetal attachment. } \\
\text { and }\end{array}$ & $\begin{array}{l}\text { The study says that } \\
\text { pregnant women with } \\
\text { high risk conditions are } \\
\text { prone to have } \\
\text { depression and perceive } \\
\text { their relationship as less } \\
\text { satisfying with the } \\
\text { family members. So, } \\
\text { effective support and } \\
\text { psychiatric consultation } \\
\text { are needed for the high } \\
\text { risk antenatal mother to } \\
\text { reduce the stress level } \\
\text { and for better outcome } \\
\text { of pregnancy. }\end{array}$ \\
\hline
\end{tabular}




\section{Results:-}

Review of all the 8 studies resulted in four main categories:-

The first category of results found from the lived experiences of hospitalized pregnant women who were interviewed and data analysis revealed some themes under which the needs can be categorized. These themes are: need for improved environment, need for social support, assistance with emotional adaptation, accepting of hospitalization, need for consultation on different problems like physical, psychological and marital (Kent et al., 2014, Janighorban et al., 2016).

The second category of results were found related to problems faced by high risk pregnant women during bed rest in which following themes emerged: social and personal meaning of family, losing normal life and child bearing, sources of stress, being in helpless and dependent state, putting aside of normal values and abiding limitations of freedom (Leichtentritt et al., 2005, Bendix et al., 2013).

The third category of results had identified that antenatal women with high risk condition on bed rest has high level of stress, anxiety and depression and lower level of spiritual well-being. So they develop some supportive needs which will help them to cope with the situation (Villar et.al, 1991., Denis et.al, 2012., \& Dunn et.al, 2007).

The last category found the ineffectiveness of psychosocial support during bed rest in high risk pregnancy and it does not improve the health status of women and fetus ( Villar et al., 1991).

Analysis of the results can be mainly categorized in three themes: need for consultation on different problems, need for emotional and social support and needs to reduce stress and anxiety.

\section{Need For Consultation on Different Problems:-}

This need of mother should be fulfilled by consulting on various problems which a high risk pregnant woman feels during bed rest. This includes need for consultation on different problems like physical, psychological, marital, acceptance of hospitalization, confidence in activity restriction, helpless and dependent state.

"My back is killing me due to inactivity. My waist makes sound when I move in my bed. Also my Knees became numb"

"The doctor told me that this illness affects the baby, so I was very concerned for my baby...I am really sad. Why did this have to happen to me? ...I cried, I cried and cried and cried..."

"Now we live at my mother in low's house. When my husband comes home he first talks with his mom and dad about job. The time that we used to talk; now he spends with his family. I am not sad but I have needs too. I need his emotional attention"

\section{Need For Emotional and Social Support:-}

This need can be fulfilled by the health care professionals, family members, relatives and friends so that the mother would not feel lonely.

"I am suffering, it is not easy to leave your family and friends and just be here all the time...I am alone, I am meant to be experiencing this pregnancy with my husband... I am depressed and nobody comes to me; it makes me feel worse, I feel lonely...I cry every night like a child when my husband says good bye and leaves me behind...I feel lonely especially at night in this single bed on my own."

"I really believe I need people to support me; I need my family and I need the staff to get me through this...I know the nurses are busy, but it would be nice to have some of their attention. I can talk to my roommate, but sometimes she is quiet and I think she feels the same as me. The doctor only comes in for half a minute every day just to say hello, then off he goes...I live for visiting times."

\section{Needs To Reduce Stress and Anxiety:-}

Stress, anxiety and depression are commonly experienced by high risk pregnant women during bed rest. Factors moderating stress and anxiety can be reduced by supportive groups. 
"I can't even sleep and I will be woken up by some routine...I have to wake up every four hours to have my blood pressure taken, so I do not get enough sleep ...I am always wondering what I can do next."

\section{Discussion:-}

The findings of present review were that bed rest during high risk pregnancy is a crucial time for pregnant women. High-risk pregnant conditions leads to long duration of hospitalization, as strict bed rest is better followed in a hospital. Data attained from review emerged in three themes: need for consultation on different problems, need for emotional and social support and needs to reduce factors of stress and anxiety.

Two studies have clearly identified the needs of the mother during bed rest and they are need for improved environment, social support, assisting with emotional adaptation, accepting of hospitalization, consultation on different problems like physical, psychological and marital (Kent et al., 2014, Janighorban et al., 2016).

All the high risk antenatal patients on bed rest develop worries related to their family relationships, household tasks $\&$ care of other children. They also feel the sense of being without control, being in helpless and dependent state (Leichtentritt et al. 2005, Bendix et al., 2013). To address these problems high risk pregnant women need some specific support like psychosocial, emotional \& physiological to cope with the situation.

Two of the studies revealed that specific support is needed during bed rest in high risk pregnancy but, the findings of these studies were that psychosocial support during bed rest in high risk pregnancy was ineffective and it did not improved the health status of women and foetus (Denis et al., 2012, Villar et al., 1991)

\section{Limitations:-}

The search that was carried out was within a publication period of 1991-2016. Due to financial constraints, the review is limited to the full text articles free to be accessed because neither translators nor paper articles costs were feasible. Only four databases were used to carry out this literature review.

\section{Conclusion:-}

Bed rest interrupts the natural process of pregnancy due to which high risk pregnant mother may sometime feel isolated. During prolonged hospitalisation, the patients develop social, environmental, emotional and adaptation needs and found it difficult to accept prolonged hospitalisation. During hospitalization, the high risk pregnant women have high level of stress and anxiety and worries. The explored themes would help the nurses to identify the needs of high risk pregnant women during bed rest and provide comprehensive care to meet them.

\section{References:-}

1. Ann E. Sprague.(2004).The Evolution of Bed Rest as a Clinical Intervention.Journal of Obstetric Gynecologic \& Neonatal Nursing, 33(5), 542-549.

2. Maloni (2010). Antepartum bed rest for pregnancy complications: efficacy and safety for preventing preterm birth. Biological Research for Nursing, 12(2), 106-124.

3. TabassumBarnagarwala (2014). India has highest number of maternal deaths. Retrieved from indianexpress.com

4. Granheim U, Lundman B. Qualitative content analysis in nursing research: concepts, procedures and measures to achieve trustworthiness. Nurse EducationToday. 2004. Availableat: http://www.nurseeducationtoday.com/ article/ S0260-6917\%2803\%2900151-5/abstract

5. Heaman\&Maureen(1998). Psychosocial impact of high-risk pregnancy: Hospital and home Care. Journal of Clinical Obstetrics \& Gynecology, 41(3), 626-639.

6. Qiao YX, Wang J., Ablat A. The prevalence and related risk factors of anxiety and depression symptoms among Chinese pregnant women in Shanghai. Journal of Obstetrics and Gynaecology. 2009;49: 185-190.

7. Roxane Agnes Kent, MCur.,MariathaYazbek, Tanya Heyns., \& Isabel Coetzee.(2014). The support needs of high- risk antenatal patients in prolonged hospitalization. Elsevier Publication, 31,164-169.

8. MojganJanighorban, FatemehMohammadi., Maryam Allahdadian, AzamDadkhah., \& Ahmad-aliEslami. (2016). Need for Consultation and Training during bed rest in women with High-risk pregnancy experience: A Qualitative Study. International journal of pediatrics, 4(5), 1705-1714. 
9. Jose Villar, UbaldoFarnot., Fernando Barros, Cesar Victoria., \& Ana Langer, Jose M Belizan. (1991). A randomized trial of psychosocial support during high risk pregnancy. The New England Journal of Medicine. 327(18), 1266-1271.

10. Denis, P. Michaux., \& S. Callahan. (2012). Factors implicated in moderating the risk for depression and anxiety in high risk pregnancy. Journal of Reproductive and Infant Psychology, 30(2), 124-134.

11. Linda L. Dunn, Marilyn C. Handley., \& Marvin Mitchell Shelton.(2007). Spiritual well-being, anxiety and depression in antepartal women on bed-rest. Issues in Mental Health Nursing, 28, 1235-1246.

12. Ronit D. Leichtentritt, Nurith Blumenthal., \&AnatElyassi, SigiRotmensc. (2005). High-risk pregnancy and hospitalization: The women's voices. National Association of Social Workers, 30(1), 39-47.

13. Jane Bendix, Hanne Kjaergaard.,\&VibekeZoffmann.(2013). Pregnant women's management of activity restriction during hospitalisation: A question of yielding and not feeling deprived of a sense of control. Journal of Neonatal Nursing, 1-7, Retrieved from http://dx.doi.org/10.1016/j.jnn.2013.04.011.

14. Anna R. Brandon, Madhukar H. Trivedi., Linda S. Hynan, Paula D. Miltenberger., Dana Broussard Labat, Jamie B. Rifkin., \& and C. Allen Stringer.(2008). Prenatal Depression in Women Hospitalized for Obstetric Risk. Journal of Clinical Psychiatry, 69(4), 635-643. 